\title{
PENGEMBANGAN INSTRUMEN PENILAIAN SIKAP SOSIAL BERBASIS PROYEK PADA PEMBELAJARAN FISIKA SMA
}

\author{
Sriyono \\ Universitas Muhammadiyah Purworejo \\ e-mail: sriyono44@gmail.com
}

\begin{abstract}
ABSTRAK
Penelitian ini dilakukan untuk menghasilkan instrumen penilaian sikap sosial berbasis proyek pada pembelajaran fisika.Pengembangan instrumen sikap sosial dilakukan melalui delapan (8) langkah, yaitu: (1) menyusun spesifikasi instrumen; (2) telaah instrumen; (3) melakukan uji coba terbatas; (4) menganalisis instrumen (5) memperbaiki instrumen; (6) melakukan ujicoba luas; (7) Menafsirkan hasil; (8) instrumen final. Subjek penelitian yang digunakan adalah 112 siswa kelas X SMA, yang terdiri dari 45 siswa laki-laki dan 65 siswa perempuan. Pengumpulan data dilakukan dengan menggunakan lembar validasi ahli. dan angket. Validasi isi dilakukan oleh 3 expert judgment dengan Agreement Index0,830. Hasil analisis factor menunjukan bahwa dari 34 item mengelompok menjadi 7 faktor yaitu: 1) perilaku jujur, 2) disiplin, 3) tanggung jawab, 4) toleransi, 5) gotong-royong, 6) santun dan 7) percaya diri, denganreliabilitas Alpha Cronbach0,919.
\end{abstract}

Kata kunci: Instrumen Sikap Sosial, penilaian projec

\section{PENDAHULUAN}

Keberhasilan pendidikan bukan saja diukur dari tingkat pencapaian kompetensi pengetahuan yang telah dicapai oleh siswa. Akan tetapi yang tidak kalah penting sebagai ukuran keberhasilan terebut adalah konpetensi sikap, spiritual dan keterampilan. Hal ini sejalan dengan pengembangan kurikulum 2013 dalam rangka meningkatkaan dan menyeimbangkan soft skills dan hard skills yang meliputi aspek sikap, keterampilan dan pengetahuan (Fadlillah, 2014: 16). Totalitas kompetensi terebut akan menghasilkan individu cerdas dan berkarakter yang mampu berkontribusi dalam membangun masyarakat.

Hasil observasi di lapangan menunjukkan bahwa penilaianterhadap kompetensipengetahuan lebih menjadi prioritas indicator keberhailan siswa. Guru cenderung melakukan penilaian pada aspek pengetahuan, dan sedikit melakukan penilian dalam aspek sikap dan keterampilan (Wijayanti, 2014).Padasatu sisi padatnya 
tugas yang harus dikerjakan guru baik di dalam maupun di luar kelas menjadikan guru mengalami kesulitan dalam menyiapkan instrument penilaian non tes. Pada sisi yang lain, kurangnya kemampuan guru dalam mengembangkan instrument penilaian non tes mungkin menjadi alasan utama penilaian terhadap kompetensi sikap kurang mendapat perhatian.

Pengembangan instrumen penilaian afektif secara nyata dibutuhkan pendidik dalam rangka mengoptimalisasi hasil yang diperoleh dari kegiatan pembelajaran, terlebih lagi untuk mata pelajaran sains. Hal ini sesuai dengan penelitian Kusumawati (2015), yang mengungkapkan bahwa penilaian sikap menggunakan instrumen hasil pengembangan dapat membuat prosesnya lebih bermakna, obyektif, dan komprehensif.

Fisika sebagai salah satu pelajaran sains merupakan suatu ilmu berlandaskan eksperimen yang pengembangan dan aplikasinya menuntut standar tinggi pada kerja eksperimental (Haksani, 2013). Keberhasilan dan kebermaknaan pembelajaran fisika sangat terkait dengan sinergis antara pemaparan konsep di kelas dengan kegiatan praktikum di laboratorium (Mariati dan Riska, 2012). Kegiatan pengamatan dan eksperimen dalam pembelajarannya fisika membutuhkan sikap tanggung jawab dan kejujuran ketika mengumpulkan dan menganalisis data.

Berdasarkan kurikulum 2013 kompetensi sikap terdiri dari sikap spiritual dan sikap sosial. Sikap sosial adalah kesadaran individu menemukan perbuatan yang nyata terhadap objek sosial atau yang berhubungan dengan pergaulan terhadap masyarakat (Ahmad, 1998). Seorang siswa dengan sikap positif yang tinggi menunjukkan tingkat akademik yang tinggi (Nolandkk, 2012). Sikap sosial yang dapat dinilai berdasarkan kompetensi sikap sosial adalah perilaku tanggung jawab, menghargai orang lain, jujur, demokratis serta bijaksana (Tim Penyusun, 2013).

Hal ini sesuai dengan Kompetensi Inti(KI)2: menghayati dan mengamalkan perilaku jujur, disiplin, tanggung jawab, peduli (gotong royong, karjasama, toleran, damai) santun, responsif dan proaktif dan menunjukkan sikap sebagai bagian dari solusi atas berbagai permasalahan dalam berinteraksi secara efektif dengan lingkungan sosial dan alam (Silabus KimiaSMA kelas XI, Kurikulum 2013). Asesmen sikap sosial 
dapat dinyatakan sebagai penilaian terhadap sikap peserta didik yang ditunjukkan melalui suatu perbuatan peserta didik terhadap proses pembelajaran dan nilai-nilai tertentu yang ditanamkan melalui materi tertentu (Majid,2007).

Penilaian sikap sosial penting dalam mendukung keberhasilan pembelajaran pada ranah kognitif dan psikomotorik. Peserta didik yang memiliki sikap positif terhadap suatu pelajaran, diharapkan akan mencapai hasil pembelajaran yang optimal(Stiggins,1994). Kurangnya perhatian terhadap sikap sosial menimbulkan masalah dalam kecerdasan emosi peserta didik (Darmansyah, 2014). Peserta didikyang sulit mengontrol emosi, akan mengalami kesulitan belajar dan bergaul terhadap lingkungan sosialnya.

\section{METODE PENELITIAN}

Pengembangan instrumen sikap sosial ini dilakukan dengan mengacu pada pengembangan instrumen afektif (Mardapi, 2012: 149), yang terdiri atas delapan (8) langkah, yaitu: (1) menyusun spesifikasi instrumen; (2) telaah instrumen; (3) melakukan uji coba terbatas;(4) menganalisis instrumen (5) memperbaiki instrumen; (6) melakukan ujicoba luas; (7) Menafsirkan hasil; (8) instrumen final. Subjek penelitian yang digunakan adalah 110 siswa kelas X SMA,yang terdiri dari 45 siswa laki-laki dan 65 siswa perempuan. Pengumpulan data dilakukan dengan menggunakan lembar validasi ahli. dan angket. Validasi isi dilakukan oleh 3 expert judgment dan selanjutnya dianalisis menggunakan Agreement Index, sedangkan hasil ujicoba instrument dianalisis dengan menggunakan analisis factor dan reliabilitas Cronback Alpha.

\section{HASIL PENELITIAN DAN PEMBAHASAN}

Hasil studi pustaka yang telah dilakukan dengan analisis KI-KD, dan silabus diketahui bahwa sikap sosial yang penting untuk dicapai adalah perilaku jujur, disiplin, tanggungjawab, toleransi, gotong-royong, santundan percaya diri. Hasil studi pustaka ini selanjutnya dikembangkan menjadi kisi-kisi instrument sikap sosial. Setelah kisi-kisi terbentuk, selajutnya dilakukan penulisan instrument sikap sosial dan menghasilkan draf instrument sikap sosial . 
Draf instrumen asesmen sikap sosial yang telah dikembangkan selanjutnya divalidasi oleh tiga validator.Rerata skor hasil penilaian validator terhadap intrumen yang dikembangkan diajikan pada Tabel 1.

Tabel 1. Hasil Penilian Validator

\begin{tabular}{clcc}
\hline No. & \multicolumn{1}{c}{ Aspek Yang Dinilai } & Rerata Skor & Kriteria \\
\hline 1 & Bahasa & 3,4 & Baik \\
2 & Materi & 3,70 & Sangat Baik \\
3 & Konstruksi & 3,86 & Sangat Baik \\
4 & Penampilan & 3,80 & Sangat Baik \\
\hline
\end{tabular}

Pada aspek bahasa, intrumen asesmen sikap sosial yang dikembangkan memperoleh skor 3,24 dengan kriteria baik. Artinya, intrumen asesmen sikap sosial yang dikembangkan telah menggunakan bahasa Indonesia yang baik dan benar, jelas, komunikatif, efektif, tidak menimbulkan makna ganda. Sedangkan pada aspek materi, instrumen asesmen sikap sosial yang dikembangkan memperoleh skor 3,70 dengan kriteria sangat baik. Artinya, terdapat kesesuaian antara instrument yang dituliskan dengan indikator sikap sosial yang ditetapkan.

Pada aspek kontruksi, menunjukkan bahwa instrumen asesmen sikap sosial yang dikembangkan memiliki kriteria sangat tinggi dengan skor 3,86. Artinya, instrumen asesmen sikap sosial yang dikembangkan telah memiliki petunjuk penggunaan dan penskoran yang jelas. Sedangkan pada aspek penampilan, menunjukkan bahwa instrumen asesmen sikap sosial yang dikembangkan memiliki kriteria sangat tinggi dengan skor 3,80. Artinya, instrumen asesmen sikap sosial yang dikembangkan telah memiliki penampilan yang menarik dengan layout yang rapi.

Di samping analisis kuantitatif tersebut di atas, analisis kecocokan penilaian juga dilakukan. Hasil analisisis Anava menunjukkan F sebesar 0,548 $<3$ dengan signifikansi P-value sebesar $0,580>0,05$. Artinya tidak terdapat perbedaan yang signifikan penilaian yang diberikan oleh para rater, dengan tingkat kesepakatan sebesar 0,830.

Setelah dilakukan validasi oleh ahli, tahap selanjutnya dilakukan uji coba terbatas. Uji coba terbatas dilakukan terhadap 3 siswa. Hasil uji coba terbatas menunjukkan bahwa instrument sikap sosial yang dikembangkan mampu dimengerti dan tidak menimbulkan makna ganda. 
Tabel 2. KMO and Bartlett's Test

\begin{tabular}{llr}
\hline \multicolumn{2}{l}{ Kaiser-Meyer-Olkin Measure of Sampling } & .728 \\
Adequacy. & & \\
\hline Bartlett's Test of & Approx. Chi-Square & $3.450 \mathrm{E} 3$ \\
Sphericity & df & 561 \\
& Sig. & .000 \\
\hline
\end{tabular}

Setelah dilakukan uji coba terbatas, selanjutnya dilakukan uji coba luas dengan melibatkan 110 siswa. Hasil analisis kelayakan dari uji coba luas seperti pada Tabel 2 menunjukkan besarnya koefisien KMO>0,5 adalah 0,728 dan korelasi tiap-tiap item MSA koefisien ' $a$ ' > 0,5 dengan rata-rata MSA sebesar 0,858. Artinya bahwa instrumen sikap sosial yang dikembangkan dapat dilanjutkan untuk dilakukan analisis faktor.

Tabel 3. Hasil Rotasi Analisis Validitas Konstruk Instrumen

\begin{tabular}{|c|c|c|c|c|c|c|c|}
\hline & \multicolumn{7}{|c|}{ Component } \\
\hline & 1 & 2 & 3 & 4 & 5 & 6 & 7 \\
\hline NO 1 & & .829 & & & & & \\
\hline NO 2 & & .779 & & & & & \\
\hline NO 3 & & .813 & & & & & \\
\hline NO 4 & & .761 & & & & & \\
\hline NO 5 & & .828 & & & & & \\
\hline NO 6 & & & & .826 & & & \\
\hline NO 7 & & & & .679 & & & \\
\hline NO 8 & & & & .682 & & & \\
\hline NO 9 & & & & .763 & & & \\
\hline NO 10 & & & & .840 & & & \\
\hline NO 11 & & & & & & .791 & \\
\hline NO 12 & & & & & & .707 & \\
\hline NO 13 & & & & & & .710 & \\
\hline NO 14 & & & & & & .870 & \\
\hline NO 15 & & & & & & .675 & \\
\hline NO 16 & & & .833 & & & & \\
\hline NO 17 & & & .808 & & & & \\
\hline NO 18 & & & .829 & & & & \\
\hline NO 19 & & & .814 & & & & \\
\hline NO 20 & & & .836 & & & & \\
\hline NO 21 & & & & & & & .882 \\
\hline NO 22 & & & & & & & .871 \\
\hline NO 23 & & & & & & & .679 \\
\hline NO 24 & & & & & & & .866 \\
\hline
\end{tabular}


NO $26 \quad .783$

NO $27 \quad .788$

NO $28 \quad .775$

NO $29 \quad .821$

NO $30 \quad .823$

NO $31 \quad .851$

NO $32 \quad .756$

NO $33 \quad .771$

NO $34 \quad .731$

Delapan faktor yang terbentuk, menunjukkan bahwa hanya ada delapan faktor yang paling bagus untuk meringkas dari keseluruhan item penilaian sikap sosial oleh siswa.

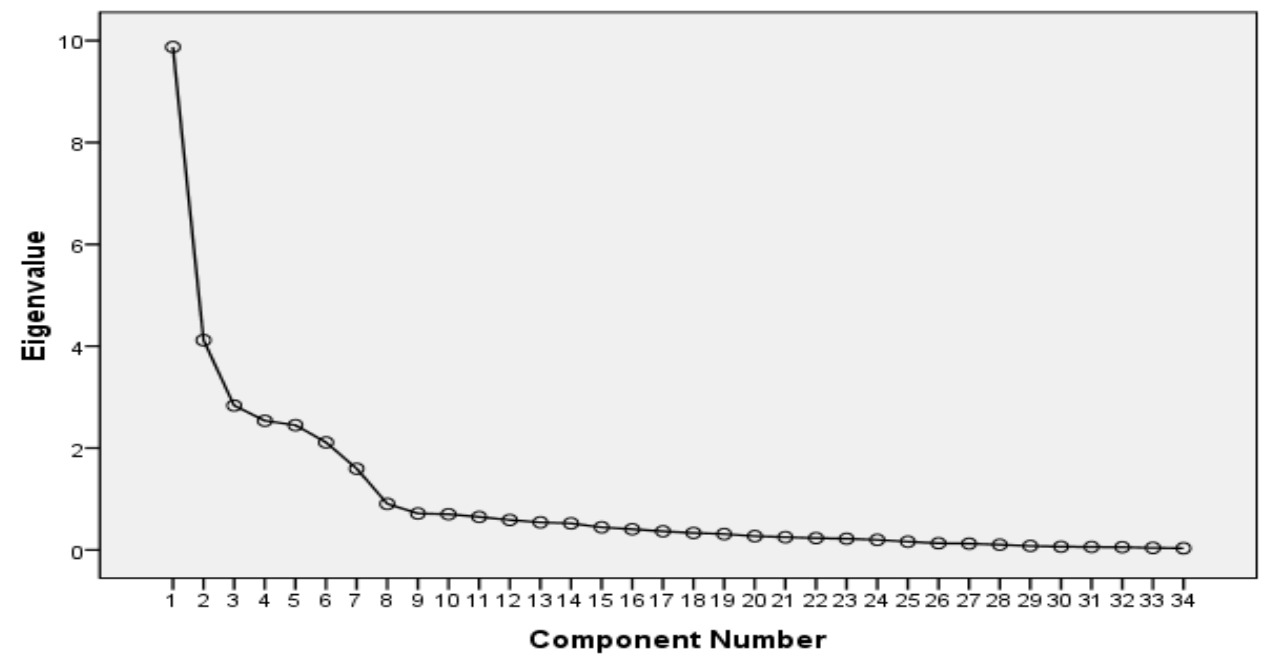

Gambar 1. Scree Plot intrumen sikap sosial

Hasil analisis faktor rata-rata validitas instrumen sebesar 0,767 pada uji coba kedua dan sebesar 0,576 pada uji coba pertama. Berdasarkan hasil dari Rotation Component Matrix menunjukkan pengelompokan dari 34 item menjadi 7 faktor yang dapat digunakan untuk penilaian sikap sosial. Tujuh faktor sikap sosial siswa tersebut, yaitu 1) perilaku jujur, 2) disiplin, 3) tanggung jawab, 4) toleransi, 5) gotong-royong, 6) santun dan 7) percaya diri. 
Tabel 4. Reliabilitas

\begin{tabular}{cc}
\hline Cronbach's Alpha & N of Items \\
\hline .919 & 34 \\
\hline
\end{tabular}

Reliabilitas instrumen penilaian sikap sosial berdasarkan uji coba luas sebesar 0,919 . Berdasarkan kriteria reliabilitas bahwa, Instrumen penilaian dikatakan reliabel jika $\bar{r} x x>0,6 ; 0,83>0,6$ (Suharsimi A. 2008:75).

Pengembangan instrumen merupakan kegiatan membuat instrumen baru atau mengembangkan instrumen yang sudah ada dengan mengikuti prosedur pengembangan secara sistematis. Prosedur pengembangan instrumen melibatkan kegiatan identifikasi variabel, deskripsi teori atau materi, pengembangan spesifikasi uji coba, dan komplikasi. (Purwanto, 2007: 99-100).

Penggunaan instrumen penilaian diri oleh siswa untuk turut menilai diri sendiri melalui instrumen penilaian karakter percaya diri yang bertujuan untuk mengetahui pencapaian karakter percaya diri melalui proses pembelajaran yang diikuti. Penilaian diri dapat membantu untuk menentukan standar keunggulan (Ross dan Bruce 2007).Siswa yang telah memiliki pengalaman penilaian diri sendiri dengan instrumen yang valid dan reliabel dapat meningkatkan rasa percaya diri, dimana penilaian diri dapat digunakan sebagai sarana pembelajaran (Coe 1988; Sargcant et al), hal ini dapat ditafsirkan penilaian diri sebagai pengalaman belajar (Colliver et al. 2005; Ross dan Bruce 2007).

Efek dari penilaian guru masih terbatas, penilaian yang dikombinasikan dengan penilaian diri oleh siswa memiliki efek yang lebih baik (Rene'e E. Stalmeijer et al. 2010). Agboola A. dan Kaun Chen Tsai, 2012 mengemukakan perlunya kerjasama para stakeholders dalam mendorong siswa untuk mewujudkan nilai-nilai yang baik dalam hidup mereka, hal ini tentu dapat menunjukkan bahwa penilaian guru terhadap siswa tidak hanya dapat menggunakan penilaian guru saja, akan tetapi juga dapat melibatkan siswa dalam menilai diri sendiri.

Hasil akhir pengembangan instrumen dibuat dalam bentuk buku panduan yang berfungsi untuk cara penggunaan instrumen untuk penilaian diri oleh siswa, penelitian ini telah menghasilkan produk pengembangan berupa instrumen penilaian karakter 
percaya diri oleh siswa SMP yang valid dan reliabel. Hal ini sesuai dengan pendapat (Puji Astuti, W. Wibawanto, H. \& Khumaedi, M; 2015; Yumaroh, Wahyu Lestari, Masrukan; 2014) menyatakan bahwa hasil akhir penelitian menghasilkan produk pengembangan yang valid, reliabel dan diwujudkan dalam bentuk panduan.

\section{KESIMPULAN}

Hasil validasi ahli menunjukkan bahwa instrumen sikap sosial yang dikembangkan valid dan melalui uji beda One Way Anova tidak terdapat perbedaan antara penilai serta tingkat reliabilitas melalui analisis ICC kategori tinggi.Hasil analisis faktor exploratori diperoleh bahwa7 faktor sikap sosial,yaitu 1) perilaku jujur, 2) disiplin, 3) tanggung jawab, 4) toleransi, 5) gotong-royong, 6) santun dan 7) percaya diri. Reliabilitas instrumen penilaian sikap sosial sebesar 0,919dan masing-masing item telah mengelompok berdasarkan factor-faktor yang ditetapkan.

\section{DAFTAR PUSTAKA}

Agboola, A. dan Tsai, K. Chen. (2012). Bring Character Education into Classroom. EuropeanJournal of Educational Research. Vol. I No. 2 (163-170).

Ahmad, S. (1998). Menumbuhkan Sikap Sosial, Moral, dan Spritual Anak DalamKeluarga Muslim. Mitra Pustaka. Yogyakarta.

Angelis, De Barbara. (1997).Confidence: Percaya Diri Sumber Sukses danKemandirian. Jakarta: Gramedia Pustaka Utama.

Aqib, Z dan Sujak. (2012). Panduan dan Aplikasi Pendidikan Karakter. Bandung: Yrama Widya.

Azwar S. (2014). Reliabilitas dan Validitas, Edisi 4. Yogyakarta: Pustaka Pelajar.

Arikunto, S. (2008). Dasar-Dasar Evaluasi Pendidikan. Jakarta: Bumi Aksara.

Chang, F. dan Munoz,M.A. 2006. School Personnel Educating the Whole Child:Impact of Character Education on Teachers' Selfassessment and Student Development". Journal of Personnel Evaluation in Education. Vol. 19 (35-49).

Darmansyah. (2014). Teknik Penilaian Sikap Spritual dan Sosial dalam Pendidi-kan Karakter di Sekolah Dasar 08 Surau Gadang Nanggalo. Jurnal Al-Ta'lim Universitas Negri Padang.

Fadlillah. (2014). Implementasi Kurikulum 2013. Yogyakarta: Arr-Ruzz Media.

Khusniati, M. (2012). Pendidikan Karakter Melalui Pembelajaran IPA. Journal of Chemical Education. 
Kusaeri dan Suprananto. (2012). Pengukuran dan Penilaian Pendidikan. Graha Ilmu. Yogyakarta.

Lauster, P. 2002. Tes Kepribadian (Alih Bahasa: D.H Gulo). Edisi Bahasalndonesia. Cetakan $13^{\text {ed }}$. Jakarta: Bumi Aksara.

Majid, A. (2007). Perencanaan Pembelajaran. Bandung: PT Remaja Rosdakarya.

Mardapi, D. (2012). Pengukuran Penilaian dan Evaluasi Pendidikan. Yogyakarta: Nusa Medika

Maslow, A.H. (1968). Toward a Psychology of Being, $2^{\text {ed }}$. New York: D. Van Nostrad.

Masrukan.(2013). Asesmen Otentik Pembelajaran Matematika. Semarang: .Swadaya Manunggal.

Nolan dkk. (2012). Survey Asessing Students Attitudes Town Ard Statistics: A systematic Review of validity and Reliability. Journal of Statistic Research. 11(2), 103-123

Paltiman Lumban Gaol, Muhammad Khumaedi \& Masrukan. Jere 6 (1) , 63- 70

Coe, R. (1988). Can feedback improve teaching? A riviwer of the social science literature with a view to identifying the condition under which giving feedback to teachers will result in improved performance. Recearch Papers in Education, 13 (1), 43-66.

Puji Astuti, W. Wibawanto, H. dan Khumaedi, M. (2015). Pengembangan Instrumen Penilaian Unjuk Kerja Praktik Perawatan Kulit Wajah Berbasis Kompetensi di Universitas Negeri Semarang. IJCET 4 (1).

Purwanto. (2007). Instrumen Penelitian Sosial dan Pendidikan. Yogyakarta: Pustaka Pelajar.

Ross, J. A., \& Bruce, C D. (2007). Teacher selfassessment: A mechanisme for facilitating profesional growth. Teaching and Teacher Education, 23, 146-159.

Stiggin, R.J.(1994). Student Centered Classroom Assessment. Mac Millan College Publishing Company. New York.

Sudaryono. (2012). Dasar-Dasar Evaluasi Pembelajaran. Graha Ilmu. Yogyakarta.

Sugiyono. (2008). Metode Penelitian Pendidikan (Pendekatan Kuantitatif,Kualitatif, dan $R \& D)$ Cetakan Ke-6.Alfabeta. Bandung.

Sugiyono. (2010). Metode Penelitian Pendidikan. Pendekatan Kuantitatif, Kualitatif, dan $R \& D$. Bandung: Alfabeta.

Suharsimi, A. (2008). Dasar-Dasar Evaluasi Pendidikan. Jakarta:Bumi Aksara.

Sukmadinata, N. S. (2011). Metodologi Penelitian Pendidikan. Bandung: Remaja Rosdakarya.

Tim Penyusun. (2013). Kerangka Dasar Dan Struktur Kurikulum Sekolah Menengah Atas/Madrasah Aliyah. Jakarta: Kemedikbud.. 
Yumaroh, Wahyu Lestari, Masrukan. (2014). Pengembangan Instrumen Evaluasi Program Praktik Kerja Industri Kompetensi Keahlian Teknik Audio Video SMK. Jere 3 (2) 